\title{
Contributions of White Clover to the N,P, and Ca Concentration of Perennial Grasses
}

\author{
JAMES W. DOBSON AND E.R. BEATY
}

\begin{abstract}
Southern range forages tend to grow vegetatively for 5 months of the year. During the other 7 months, forage available is low in energy and minerals. Cattle are usually grazed on seeded pastures or fed hay from October until May. Growing of a legume with the grass is currently of major interest as it increases energy, $N$, and minerals as compared to that of the grasses grown alone. Growing white clover (Trifolium repens $L$.) with any of the five major perennial forage grasses was found to increase the $\mathbf{N}$ concentration in the forage produced all season long. Grass forages grown with white clover but without $\mathbf{N}$ averaged as high or higher in $\mathbf{N}$ concentration than monospecific grass forage fertilized at all $\mathrm{N}$ rates up to $336 \mathrm{~kg} / \mathrm{ha}$.

Phosphorus concentration of the forage was not appreciably influenced by presence of white clover but averaged $0.37 \%$ in the spring and $0.26 \%$ in the fall, a $30 \%$ reduction with season. Orchardgrass (Dactylis glomerata L.) and tall fescue (Festuca arundinacea Schreb.) forage had higher $\mathbf{P}$ concentrations than did the warm-season perennials Coastal and common bermudagrass (Cynodon dactylon L. Pers.) and dallisgrass (Paspalum dilatatum Poir.). Ca concentration of the forage was directly related to quantity of clover present. Including white clover with the perennial grasses would significantly increase the $\mathbf{N}$ and $\mathbf{C a}$ concentrations of the forage as compared to the grass alone. The increases in concentrations of $\mathrm{N}$ and $\mathrm{Ca}$ would significantly improve the nutritional quality of the grass forages being grown.
\end{abstract}

Perennial legumes such as white-clover (Trifolium repens L.) have not been widely grown on ranges in the Southeast but have been grown on seeded pastures for many years. It is generally believed that legumes improve the energy, $\mathrm{N}$, and mineral composition of seeded grass pastures; and in the South such pastures replace ranges for some 7 of the 12 months of the year. Few data are available to demonstrate the effect that adding white clover to a grass pasture will have on forage chemical concentration.

The amount of white clover grown in pasture mixtures of the southern region has varied widely. In the late 1940's, white clover, as did legumes in general, attracted considerable research attention, but during the 1950's and during most of the 1960's, the application of inorganic $\mathrm{N}$ on seeded grass pastures increased and consequently interest in growing white clover decreased. Range grazing has traditionally included native legumes but few were seeded. As the interest in growing cattle in the Southeast inceased, growing white clover in forages, including that produced on range, has increased. By 1970 , interest in high rate of $\mathrm{N}$ usage on pastures decreased and interest in including white clover in the forage mix was renewed.

\footnotetext{
Authors are superintendent, Georgia Mountain Branch Experiment Station, Blairsville, Ga. 30512; and professor, Agronomy Department, University of Georgia, Athens 30602 .

Manuscript received April 28, 1978.
}

White clover is one of the most versatile legumes and is being grown on 100,000 ha of pastures in Georgia annually. Interest is also increasing to grow white clover on ranges particularly on clear cut and wet areas.

White clover is generally considered to be one of the most nutritious legumes (Gibson and Hollowell 1966; Koger et al. 1961). In contrast to grass forages, variation in chemical concentrations between white clover samples is usually minimal (Wilkins et al. 1958) and probably is caused by the white clover dehiscing dead leaves leaving only green forage. The $\mathrm{P}, \mathrm{Ca}$, and $\mathrm{K}$ concentrations of white clover have been reported to exceed $0.35,1.50$, and $1.50 \%$ respectively (Miller 1958; Stewart and Bear 1951). White clover generally produces low forage yields and growing it with a grass prevents bloat in ruminants, improves forage quality, and increases yields (Daugherty, 1956). The purpose of this experiment was to determine the changes in $\mathbf{N}, \mathrm{P}$, and $\mathrm{Ca}$ concentration of five perennial forage grasses when grown with and without white clover and at four $\mathrm{N}$ rates.

\section{Materials and Methods}

Tall fescue, orchardgrass, dallisgrass, and 'Coastal' and common bermudagrass were grown with and without Ladino clover. Nitrogen $(\mathrm{N})$ at rates of $0,37,112$, and $336 \mathrm{~kg} / \mathrm{ha}$ was applied as $\mathrm{NH}_{4} \mathrm{NO}_{3}$ in multiple applications. The first was applied in early April and the second and third after the June 15 and August 1 forage harvest, respectively. Phosphorus ( $\mathrm{P}$ ) and potassium (K) were uniformly applied with surface applications of $560 \mathrm{~kg} / \mathrm{ha}$ of 0-4.4-16 NPK annually. Calcium $(\mathrm{Ca})$ and magnesium $(\mathrm{Mg})$ were applied as dolomitic limestone the first year of the investigation at the rate of 8 $\mathrm{mt} / \mathrm{ha}$. Treatments were replicated five times in split-plot design.

At the first harvest, May 1, plots seeded to tall fescue and orchardgrass with/without white clover were clipped. At the June 15, August 1, and September 15 harvest dates, all grasses with/withou white clover were harvested. In 1952 and 1953, forage samples from the grass/N and grass/white clover treatments were ground through a Wiley Mill in preparation for $\mathbf{N}$ determinations. In addition in 1953 forage from grass/N and grass/white clover plots collected on May 1 , August 1, and September 20 were analyzed for $\mathrm{P}$ and $\mathrm{Ca}$. At each clipping, botanical separations, grass/white clover, and grass/ $\mathrm{N}$ were made on forage from the tall fescue and Coastal bermudagrass plots.

$\mathrm{N}$ was determined by Kjeldahl while $\mathrm{P}$ and $\mathrm{Ca}$ were determined on aliquots from a solution obtained by wet ashing $1 \mathrm{~g}$ of plant material using a mixture of nitric, perchloric, and sulfuric acids. $\mathrm{P}$ and $\mathrm{Ca}$ was determined by procedures described by Piper (1944).

\section{Results and Discussion}

\section{Forage $\mathbf{N}$ Concentrations}

Increasing the $\mathbf{N}$ fertilization rate caused an increase in $\mathbf{N}$ concentration of the forage in the presence or absence of white clover (Table 1 and Fig. 1). Applying $\mathrm{N}$ as fertilizer increased 
Table 1. The effect of $N$ rate and white clover on the $N$ concentration (\%) of five forage grasses, Blairsville, Ga, 2 year average.

\begin{tabular}{lccccc}
\hline \multirow{2}{*}{\multicolumn{1}{c}{ Forage }} & \multicolumn{5}{c}{$\mathrm{N}$ rate } \\
\cline { 2 - 5 } & 0 & 37 & 112 & 336 & Mean \\
\hline Orchardgrass & 2.17 & 2.27 & 2.42 & 2.95 & 2.45 \\
Orchardgrass/white clover & 2.73 & 2.55 & 2.62 & 3.06 & 2.74 \\
& & & & & \\
Tall fescue & 2.00 & 2.28 & 2.27 & 3.03 & 2.40 \\
Tall fescue/white clover & 2.55 & 2.56 & 2.66 & 3.17 & 2.74 \\
& & & & & \\
Coastal bermuda & 1.48 & 1.43 & 1.59 & 1.86 & 1.59 \\
Coastal bermudagrass/ & 2.22 & 2.17 & 2.18 & 2.51 & 2.27 \\
$\quad$ white clover & 1.34 & 1.38 & 1.49 & 1.90 & 1.53 \\
Common bermuda & 2.01 & 2.37 & 2.36 & 2.40 & 2.29 \\
Common bermudagrass/ & & & & & \\
& 1.56 & 1.58 & 1.65 & 1.85 & 1.66 \\
Dallisgrass & 2.09 & 1.90 & 1.98 & 2.01 & 2.00 \\
Dallisgrass/white clover & & & & & \\
Mean/grass & 1.71 & 1.79 & 1.88 & 2.32 & \\
Mean/grass and clover & 2.32 & 2.31 & 2.36 & 2.63 & \\
\hline
\end{tabular}

$L S D(\mathrm{P}<0.05)=0.37 \%$

forage $\mathrm{N}$ concentration, but growing grasses with white clover produced a forage with higher amounts of $\mathrm{N}$ at all levels of fertilization than grasses grown without white clover. The difference was especially pronounced at $0 \mathrm{~N}$ fertilization, where forage with white clover had on the average $2.3 \% \mathrm{~N}$ in contrast to $1.71 \% \mathrm{~N}$ in forage without white clover. The addition of 37 or $112 \mathrm{~kg} / \mathrm{ha} \mathrm{N}$ increased average forage $\mathrm{N}$ concentration to 1.79 and $1.88 \%$ without white clover and 2.31 and $2.36 \%$ with white clover, respectively (Table 1 ).

Including white clover increased with $\mathbf{N}$ concentration of the forage approximately 0.5 percentage point or $27 \%$ of the mean as compared to that of the grasses grown alone. With the addition of $336 \mathrm{~kg} / \mathrm{ha}$ of $\mathrm{N}$, the average forage $\mathrm{N}$ concentration of the straight grass was $2.32 \%$ and grass/white clover forage that received no $\mathrm{N}$ averaged $2.32 \%$. The $\mathrm{N}$ content of the orchardgrass and tall fescue without white clover averaged $2.42 \% \mathrm{~N}$ or $0.84 \%$ higher than did the warm-season grasses $(1.58 \%)$. When white clover was added, the average $\mathrm{N}$ content of the cool-season grasses was $2.74 \%$ or $0.56 \%$ higher than that of the bermuda and dallisgrasses, which had an average $\mathrm{N}$

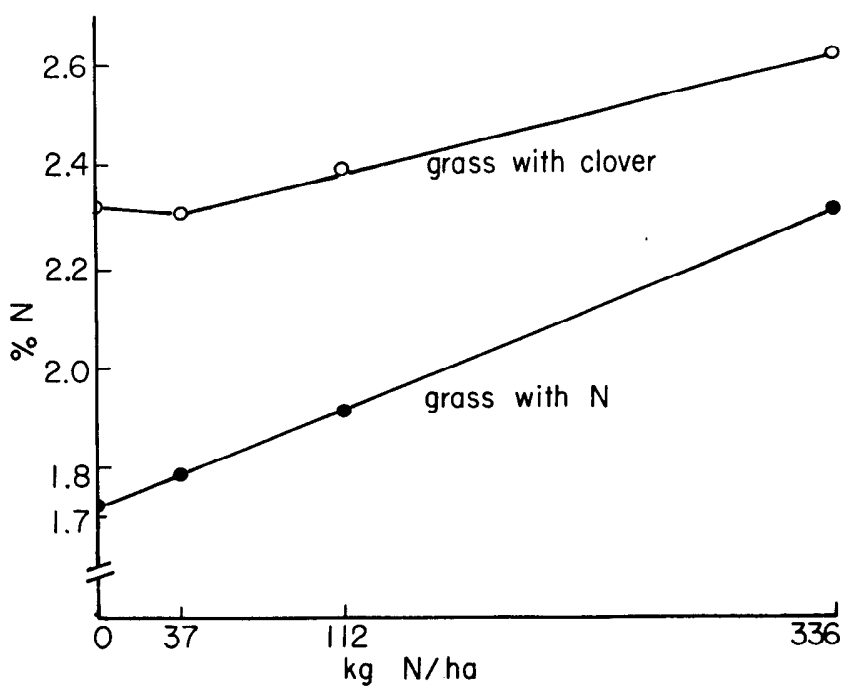

Fig. 1. Average forage $N$ concentration at four $N$ rates of tall fescue orchardgrass, dallisgrass, Coastal and common bermudagrass grown with $N$ and with white clover. Blairsville, Ga. 1952-1953. content of $2.18 \%$. The cool-season growing grasses, tall fescue and orchardgrass, produce forage that is primarily leaf, while the bermudagrass forage is high in stem.

Adequate animal nutrition requires a forage containing $1.76 \% \mathrm{~N}$ and $70 \%$ digestibility (NRC 1970). All of the cool-season forages and all forages with white clover had adequate $\mathrm{N}$. However, only when the summer growing grasses without white clover were fertilized with $336 \mathrm{~kg} / \mathrm{ha}$ of $\mathrm{N}$ was $\mathrm{N}$ concentration that high.

Nitrogen concentration of the forage composited by $\mathrm{N}$ rates and clipping dates with and without white clover is shown in Figure 2. Forage with white clover averaged $0.68 \%$ higher in $\mathrm{N}$ than forage without white clover. At the first clipping the forage $\mathrm{N}$ concentration of grass/white clover was $0.64 \%$ and at the second clipping $0.82 \%$ higher than grass with $\mathrm{N}$ only. By the third clipping the $\mathrm{N}$ concentration of the white clover/grass forage was $0.82 \%$ higher than the grass plus $\mathrm{N}$. Only at the fourth clipping was there a sizeable decrease in $\mathrm{N}$ concentration of forage with white clover. Under Southeastern conditions, fall harvest forage contained very little, less than $10 \%$ clover; yet the forage from grass/white clover plots was $0.41 \%$ higher in $\mathrm{N}$ than was the grass/ $\mathrm{N}$ forage indicating a residual $\mathbf{N}$ input to the grass from the white clover grown earlier.

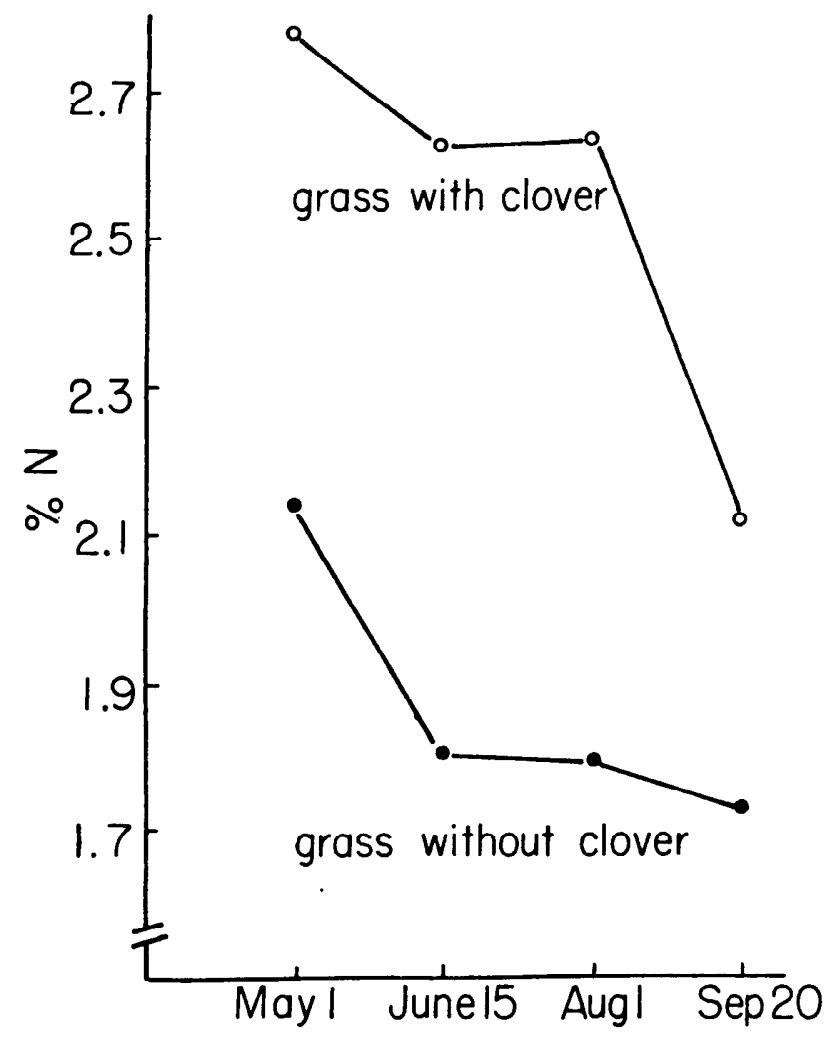

Fig. 2. Average forage $N$ concentration by harvest dates of tall fescue, orchardgrass, dallisgrass, Coastal and common bermudagrass grown with white clover and with $N$. On May 1 only plots with tall fescue and orchardgrass harvested. Data average of four N rates. Blairsville, Ga. 1952-1953.

The effect of growing white clover with a grass on the $\mathbf{N}$ concentration of the grass is shown in Figure 3 for Coastal bermudagrass and tall fescue. Grass grown with white clover was consistently higher in $\mathrm{N}$ than grass grown with $\mathrm{N}$. The $\mathrm{N}$ content of grass growing with but separated from white clover was intermediate between the grass grown with white clover and grass grown with $\mathrm{N}$. These data show that growing white 


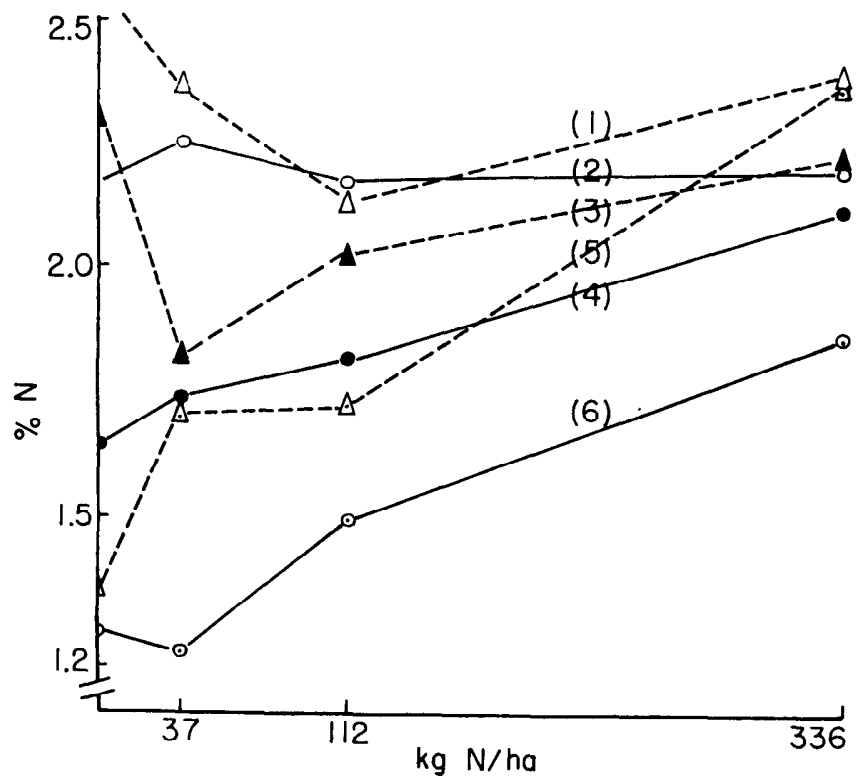

Fig. 3. Average forage $N$ concentration of tall fescue with (I) white clover, (3) separated from white clover, (5) $N$ only and Coastal bermudagrass with (2) white clover, (4) separated from white clover and (6) $N$ only at four $N$ rates. Blairsville, Ga. 1952-1953.

clover with a grass will increase the average $\mathrm{N}$ content of the forage grass by approximately $0.3 \%$ percentage point. Adding white clover to the forage mix increased the $\mathrm{N}$ content consistently in addition to a large increase in forage yield (Dobson and Beaty 1977).

\section{Phosphorus Concentration}

Phosphorus concentration of the forage including white clover was little different from that of the grass alone (Fig. 4). Forage clipped on May 1 tall fescue and orchardgrass, averaged $0.37 \% \mathrm{P}$ and decreased to an average of $0.26 \%$ by

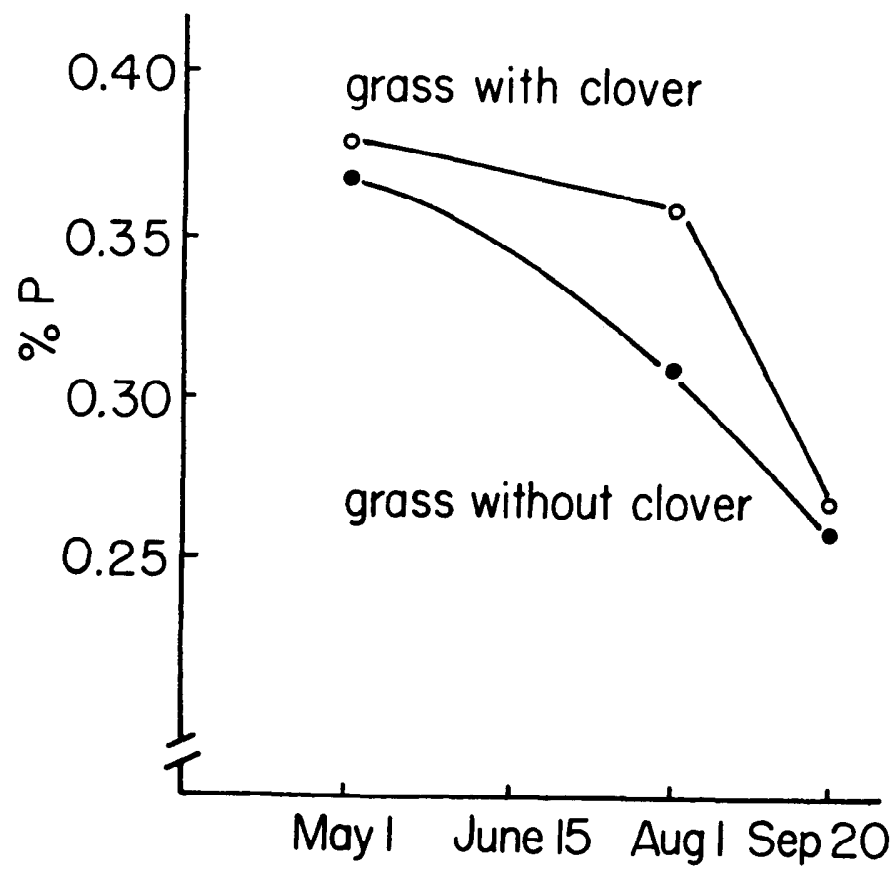

Fig. 4. Average forage $P$ concentration by harvest dates of tall fescue, orchardgrass, dallisgrass, Coastal and common bermudagrass grown with white clover and with N. On May 1 only plots with tall fescue and orchardgrass harvested. Data average of four $N$ rates. Blairsville, Ga. 1953.
September 20. Forage containing white clover averaged slightly higher in $\mathrm{P}$ than did grass alone, but the difference was not large enough to be of significance. The $P$ concentration of all forages was well above that required by animals (NRC 1970). Nitrogen fertilization did not consistently affect $P$ concentration of the forage, but the $\mathrm{P}$ concentration of tall fescue and orchardgrass was approximately $50 \%$ higher than that of dallisgrass and bermudagrasses. Tall fescue and orchardgrass forages are largely leaf and should be higher in $\mathrm{P}$ than stems. Part of the decrease in average $P$ concentration of the August 1 and September 20 harvested forage reflects the inclusion of the warm season perennials and their greater stem content.

\section{Forage Ca Concentration}

Calcium was significantly higher in the white clover/grass forage than in the grass alone (Fig. 5). At the May 1 harvest, when tall fescue and orchardgrass were harvested, Ca concentration of the white clover/grass forage was almost double that of grass alone. At the August 1 clipping, white

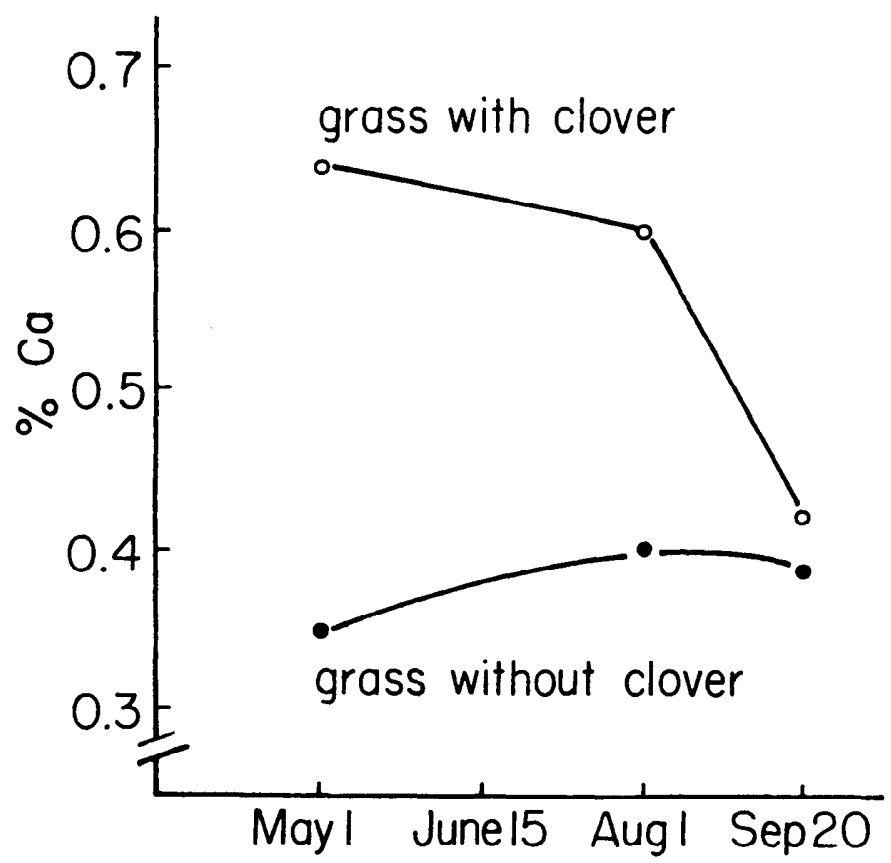

Fig. 5. Average forage $\mathrm{Ca}$ by harvest dates of tall fescue, orchardgrass, dallisgrass Coastal and common bermudagrass grown with white clover and with $N$. On May 1 only plots with tall fescue and orchardgrass harvested. Data averaged of four $\mathrm{N}$ rates. Blairsville, $\mathrm{Ga} 1953$.

clover/grass forage was still $50 \%$ higher in Ca than was grass grown with N. By the September 20 clipping, white clover had largely disappeared (Dobson and Beaty 1977) and the $\mathrm{Ca}$ concentration of white clover/grass was comparable to that of the grass plus $\mathrm{N}$. Trends of $\mathrm{Ca}$ concentration among grass species are shown in Figure 6. The Ca content of dallisgrass forage is much lower than that of orchardgrass and tall fescue and is similar to that of the bermudagrasses.

\section{Discussion}

Adding white clover to five perennial forage grasses significantly increased the $\mathrm{N}$ concentration of the forages as did applying 112 and $336 \mathrm{~kg} / \mathrm{ha}$ of $\mathrm{N}$. The increased $\mathrm{N}$ concentration in forage resulting from including white clover would be expected to produce a more nutritious forage (NRC, 1970). Adding white clover to the grasses had little influence 


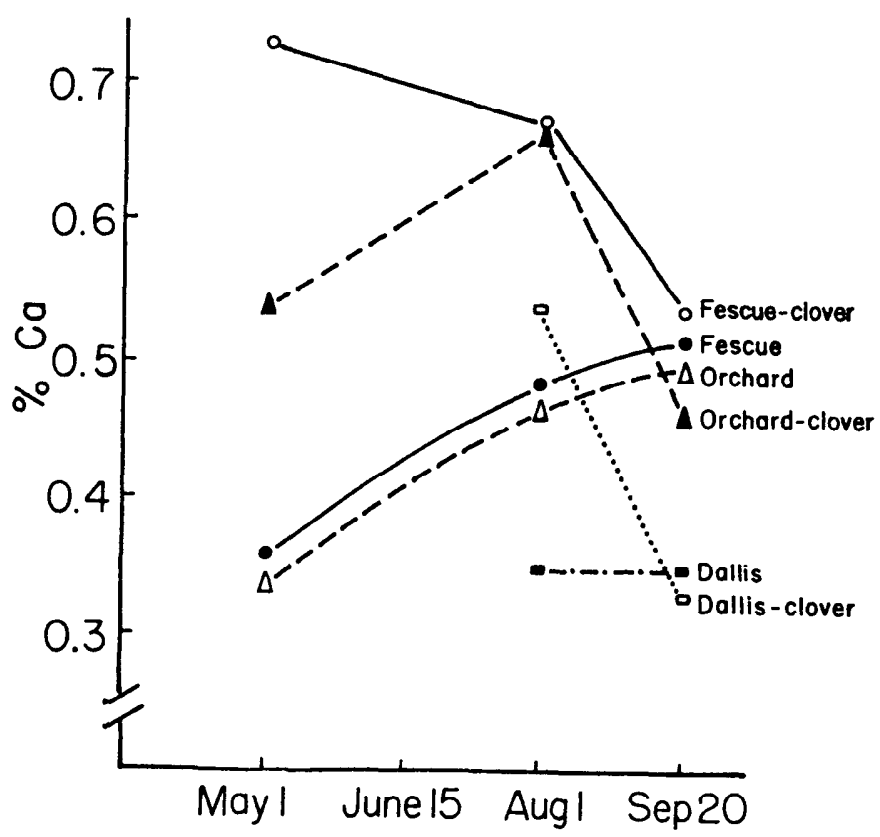

Fig. 6. Average $C$ a concentration by harvest dates of tall fescue, orchardgrass and dallisgrass grown with white clover and with $N$. Data average of four $N$ rates. Blairsville, $G a .1953$.

on the $\mathrm{P}$ concentration of the forage. Phosphorus concentration of all forages appeared to be adequate for beef cattle (NRC 1970). Calcium concentrations of the forages closely followed the percent white clover.

Perhaps the major significance of the data is that nutritionally adding white clover improved the $\mathrm{N}$ and $\mathrm{Ca}$ concentrations of the warm-season perennial forages more than that of the cool-season perennials. Adding white clover to perennial forages seeded in the lower South would appear to be especially beneficial. Native range forages, like bermudagrass, are probably less nutritious in the fall than the summer; thus when growing bermudagrasses and native grasses, including white clover in mixture would be highly desirable. If white clover cannot be grown, including another summer-growing legume should probably be considered.

Since cattle must be removed from the range for 6 to 7 months each year, alternate sources of forage to complement that range must be provided. In a previous report Dobson and Beaty (1977) showed the forage yield advantage of including white clover with grasses and present research shows that nutritional advantage of adding white clover on increasing the $\mathrm{N}$ and $\mathrm{Ca}$ concentrations. The advantage of adding a legume to range areas or to seeded pastures used to complement ranges would be highly beneficial in increasing yield and nutritional quality. The concept of growing a legume with range grasses does not appear to be widely appreciated. Biologically, growing a legume such as white clover on ranges probably offers more opportunity to increase forage nutritional yield and quality than any other practice generally available.

\section{Literature Cited}

Daugherty, R.W. 1956. Bloat in ruminants, Yearbk Agr., U.S. Dep. Agr., 1956: 108-113.

Dobson, James W., and E.R. Beaty. 1977. Forage yields of five perennial grasses grown with and without white clover at four nitrogen rates. J. Range Management 30:461-465.

Gibson, P.B., and E.A. Hollowell. 1966. White clover, U.S. Dep. Agr. Handbk 314.

Koger, M., W.G. Blue, G.B. Killinger, R.E.L. Green, H.C. Harris, J. M. Meyers, A.C. Wornick, and N. Gammon, Jr. 1961. Beef production, soil and forage analysis and economic returns from eight pasture programs in North Central Florida. Florida Agr. Exp. Sta. Bull. 631.

Miller, D.F. 1958. Composition of cereal grains and forages. Nat. Acad Sci. Nat. Res. Counc. Pub. 585.

Nutrient Requirements of Beef Cattle. 1970. Nutrient requirements of domestic animal. NRC Pub. 4. 40 p.

Piper, C.S. 1944. Soil and Plant Analysis. Interscience, New York. p. $276,291$.

Stewart, E., and F.E. Bear. 1951. Ladino clover its mineral requirements and chemical composition. New Jersey Agr. Exp. Sta. Bull. 759.

Wilkins, H.L., I.L. Lindahl, R.E. Davis, and Paul J. Reynolds. 1958. Free, reducing, acid-hydrolyzable, and total sugars and total available carbohydrates in ladino clover, nutritionally significant chemical components of forage legumes. J. Agr. Food Chem. 6:369-373.
Technicolor Graphic Services, Inc. has service contracts with the government at the EROS Data Center in South Dakota, NASA-AMES in California, and USGS in Alaska. This growing company needs top quality geoscientists, bioscientists, data analysts and technicians with experience in automated satellite and aerial remote sensing data analysis to participate in long-term critical project research and instructional activities. National and international opportunities... excellent facilities and equipment.

Interested? To discuss a strong career opportunity, call Mr. G.A. Strom at (605) 594-6511 or send your resume without delay to P.O. Box 1242, Sioux Falls, SD 57101.

\section{POSITION AVAILABLE}

The Department of Animal and Range Sciences at Montana State University is seeking two or three Range Scientists to fill newly available tenure track positions. Desired areas of specialization are Grazing Systems and Range Plant Physiology, Range Improvements, and Range Livestock Nutrition. These are teaching and research positions, on a twelve month basis. Teaching may be in various areas in addition to those mentioned above.

Applications must be received before May 1, 1980. For additional information, please write to:

\section{Dr. John E. Taylor, Chairman Search Committee \\ Dept. of Animal and Range Sciences Montana State University Bozeman, MT 59717}

Montana State University is an equal opportunityaffirmative action employer. 